\title{
Agronomic Components of Brown Linseed as a Function of Spacing
}

\author{
Dionei Schmidt Muraro ${ }^{1}$, Claudir José Basso ${ }^{1}$, Ivan Ricardo Carvalhoº ${ }^{2}$, Vinícius Jardel Szareski ${ }^{2}$, Luan Cutti ${ }^{3}$, \\ Adalin Cezar Moraes de Aguiar ${ }^{1}$, Vanessa Alba da Silva ${ }^{1}$, Marlo Adriano Bison Pinto ${ }^{1}$ \& Francine Lautenchleger ${ }^{4}$ \\ ${ }^{1}$ Department of Plant Science, Federal University of Santa Maria, Santa Maria, RS, Brazil \\ ${ }^{2}$ Department of Plant Science, Federal University of Pelotas, Capão do Leão, RS, Brazil \\ ${ }^{3}$ Department of Plant Science, Federal University of Rio Grande do Sul, Porto Alegre, RS, Brazil \\ ${ }^{4}$ Department of Plant Science, State University of Londrina, Londrina, PR, Brazil \\ Correspondence: Ivan Ricardo Carvalho, Department of Plant Science, Federal University of Pelotas, Campus \\ Capão do Leão, CEP 96050-500, Capão do Leão, RS, Brazil. E-mail: carvalhoirc@gmail.com
}

Received: May 3, $2018 \quad$ Accepted: June 5, $2018 \quad$ Online Published: September 15, 2018

doi:10.5539/jas.v10n10p527 URL: https://doi.org/10.5539/jas.v10n10p527

\begin{abstract}
The objective of this study was to evaluate the behavior of brown linseed, submitted to different spacing between lines. The experiment was carried out at the Federal University of Santa Maria, Frederico Westphalen Campus, under a typical eutrophic Red Latosol, from September to December 2013. The experimental design was a randomized complete block design with four replications and four treatments, with experimental plots of $4.0 \times$ 3.0 meters, totaling $12.0 \mathrm{~m}^{2}$. The treatments consisted of four line spaces, $17,34,51$ and $68 \mathrm{~cm}$. The following parameters were evaluated: dry matter, plant height, stem diameter, weight of one thousand seeds and grain yield. The spacing of $0.17 \mathrm{~m}$ was the one that stood out showing higher yield and agronomic characteristics favorable to the crop, such as a smaller stature of important plant from the point of view of a lower lodging and a greater production of dry matter, and consequently residual straw for cultivation in succession, this being a basic premise in areas under no-tillage system.
\end{abstract}

Keywords: Linum usitatissimum L., spatial distribution, phenotypic plasticity

\section{Introduction}

Linseed (Linum usitatissimum) is an annual plant, belonging to the Linaceae family, characterized by a height between 30 and $130 \mathrm{~cm}$, straight stems, narrow leaves, linear or lanceolate. Its main product is the oil, used for human consumption, composed of Omega 3, Omega 6 and Omega 9 (polyunsaturated fatty acids), besides presenting other basic nutritional components and antioxidant compounds, beneficial for health, allied mainly in the loss of weight and improvement of intestinal flow due to high fiber concentration (Wood, 1997; Oliveira et al., 2012). The oil content of the seeds is between $40-45 \%$, fibers $20-25 \%$ and proteins $20-25 \%$, and is also widely used by industries in the manufacture of paints, varnishes, PVC plastics, food and personal care products (Rabetafika, 2011).

World linseed production is between 2,300,000 and 2,500,000 tons per year, with Canada being its main producer. In South America, the largest producer is Argentina, with around 80 tons/year, while Brazil has a smaller production, about 21 tons/year (Almeida, 2009). Because it is not a very demanding regarding farming practices, it is often cultivated in succession to corn or soybeans, taking advantage of the residual fertilization of these crops, and thus to enable a system of crop rotation, adding economic value, and at the same time keeping the soil covered, reducing the erosion process, and promoting nutrient cycling (Soares, 2009).

The potential of linseed production, as well as many other crops, is affected by the synergy of several factors, among them the choice of the most suitable plant arrangement (Tomassoni et al., 2013). The seeding density and the spatial arrangement are determinant in the solar radiation intercepted by the canopy. The energy of the solar radiation absorbed by the plants is a determinant of the photosynthetic rate and can limit the production, the accumulation of biomass and the development of the plants (Caron et al., 2012; Aisenberg et al., 2018). The distribution of plants in the crop also affects the incidence of pathogens, by creating microclimates under conditions of high plant densities, with high humidity and low air circulation in the lower plant extracts, close to the soil (Madalosso, 2010; Carvalho et al., 2016). Silva et al. (2008) observed an increase in disease severity in 
corn crop, with reduced row spacing, due to better microclimate conditions for the development of pathogens. In addition, the interline spacing can also influence the competitive ability of the crop with weeds, placing the crop at an advantage in smaller spaces, reducing the amount of radiation reaching the weeds, and the better spatial distribution, which allows a better use of resources, such as water and nutrients.

In Rio Grande do Sul, the cultivation of linseed has aroused interest of many farmers because it presents a high commercialization price and is an alternative of rotation in the winter, since, in addition to the production of straw, it makes possible a later sowing of the soybean still within the zoning recommended for the crop. However, the information about the different spacings and about its agronomic management aiming at higher yields is scarce, even the linseed being of great industrial application and of relevant use for man. In view of the above, the objective of this work was to evaluate the behavior of brown linseed, subject to different spacing between the lines.

\section{Material and Methods}

This study was conducted in the experimental area of the Federal University of Santa Maria, campus of Frederico Westphalen, RS, in the year 2013, whose coordinates are $27^{\circ} 23^{\prime} 47.62^{\prime \prime} \mathrm{S}$ and $53^{\circ} 25^{\prime} 41.34^{\prime \prime} \mathrm{W}$, at an altitude of 566 meters. The climate, according to the classification of Maluf (2000), is of type subtropical with wet spring, with annual average temperature of $18.1^{\circ} \mathrm{C}$ and annual rainfall near $1,900 \mathrm{~mm}$. The soil is classified as a typical dystrophic red latosol (Santos et al., 2013) with a clayey texture, being cultivated under no-tillage for more than 10 years with soybean and corn crops in the summer and wheat and oats, in winter. At the time of the installation of the experiment, soil samples were collected at depths of $0-20 \mathrm{~cm}$ for soil chemical characterization The following results were found: $\mathrm{pH}$ in $\mathrm{H}_{2} \mathrm{O}$ (1:1) 4.6, SMP index 5.1, clay $650 \mathrm{~g} \mathrm{~kg}^{-1}$, organic matter $2.7 \mathrm{~g} \mathrm{~kg}^{-1}$, P-mehlich $7.2 \mathrm{mg} \mathrm{dm}^{-3}$, potassium $137 \mathrm{mg} \mathrm{dm}^{-3}$, calcium $2.1 \mathrm{cmol}_{\mathrm{c}} \mathrm{dm}^{-3}$, magnesium $1.2 \mathrm{cmol}_{\mathrm{c}} \mathrm{dm}^{-3}, \mathrm{H}+\mathrm{Al} 8.0$ $\mathrm{cmol}_{\mathrm{c}} \mathrm{dm}^{-3}, \mathrm{Al} 2.1 \mathrm{cmol}_{\mathrm{c}} \mathrm{dm}^{-3}, \mathrm{CEC} 11.6 \mathrm{cmol}_{\mathrm{c}} \mathrm{dm}^{-3}$, and a percentage of CEC with bases and Al of 31.3 and $36.5 \%$, respectively. Six months before the installation of the experiment, limestone was applied for raising $\mathrm{pH}$ to 6.0 following recommendation of CQFS-RS/SC (2004).

The treatments consisted of different spacing between lines: 17, 34, 51, $68 \mathrm{~cm}$. The experimental design was a randomized complete block design, with four replications, with experimental plots of $4.0 \times 3.0$ meters, totaling $12.0 \mathrm{~m}^{2}$.

The experiment was installed under soybean residue. In pre-sowing, the area was desiccated with the glyphosate herbicide, and after 30 days, on 09/09/2013, the manual seeding of the brown linseed with a density of $30 \mathrm{~kg}$ ha-1 was performed. Nitrogen, phosphatic and potassium fertilization were carried out uniformly between treatments, by top-dressing, following the recommendation of CQFS-RS/SC (2004). Weed control was done manually. The experiment was harvested on 12/18/13. The crop presented a cycle of 101 days, with precipitation distribution favorable to the development of the crop. During the course of the experiment $593.2 \mathrm{~mm}$ of precipitation were recorded (Figure 1).

The evaluations were:

Dry matter: An area of $0.25 \mathrm{~m}^{2}$ was sampled in full flowering to evaluate the dry matter of the aerial part of the linseed. The samples were dried in an oven with circulation of air and temperature of $65{ }^{\circ} \mathrm{C}$ until reaching constant weight.

Plant height: Measured by the distance between the base of the plant and the upper part of the highest panicle, being carried out in 10 random plants within the useful area of each plot.

Stem diameter: It was carried out in 10 randomly collected plants, with the aid of a pachymeter, being read at approximately $5 \mathrm{~cm}$ from the base of the plant.

Weight of one thousand seeds: random sampling and weighing of eight samples of 100 grains of each replicate, the values corrected to $13 \%$ of humidity.

Grain yield: Evaluated by manual harvesting of the three central lines, discarding $0.3 \mathrm{~m}$ from each end of the plot. The trail was made with mechanical equipment. The weight of the grains was corrected to $13 \%$ moisture. 


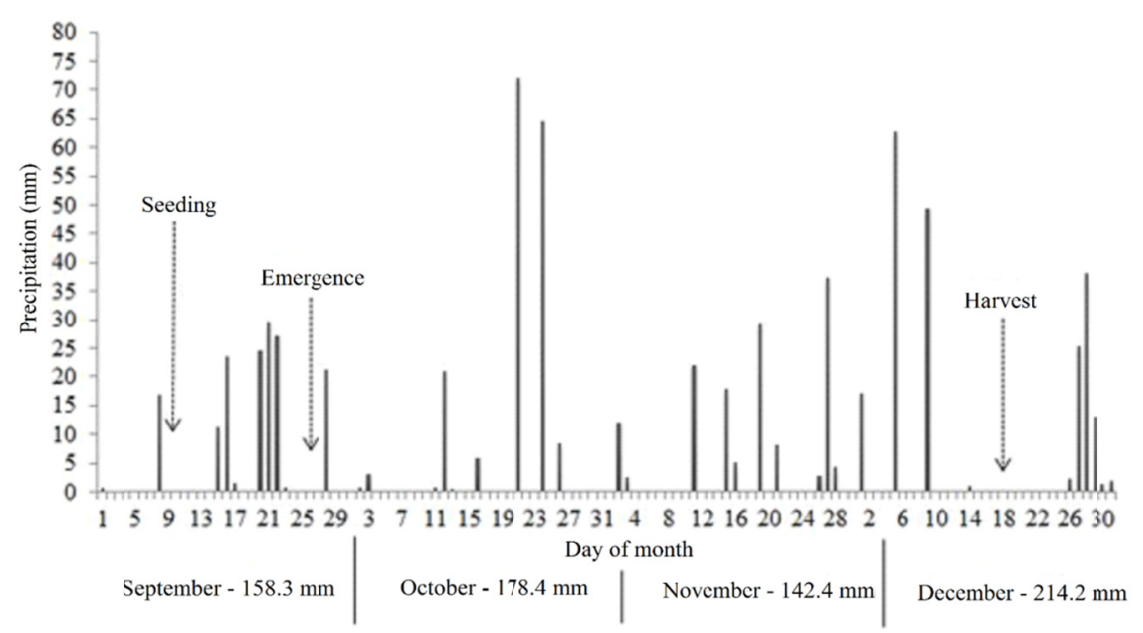

Figure 1. Daily precipitation occurred during the experiment and dates of sowing, emergence and harvest of brown linseed. Data obtained at the UFSM meteorological station, Frederico Westphalen Campus, RS

(CPTEC/INPE)

For the data obtained, the analysis of variance was performed by the $\mathrm{F}$ test at $5 \%$ of error probability. Obtaining Significance, the data were submitted to the regression adjustment. For these analyzes, the statistical program Assistat 7.7 beta was used.

\section{Results and Discussion}

The $17 \mathrm{~cm}$ spacing was where the plants presented smaller stature, with reduction of $8.1 \%$ when compared to the treatment with $68 \mathrm{~cm}$, that presented higher plants (Figure 2).

This may be associated with the fact that by increasing the spacing there is a higher density of plants in the line, increasing the intraspecific competition mainly by light (Sangoi, 2000; Demari et al., 2016; Szareski et al., 2016), as a consequence plants grow longer. Smaller plant heights are desirable because they are less prone to lodging. Differently from this work, Santos et al. (2014) working with spacings of 15, 30, 45 and $60 \mathrm{~cm}$ between rows, observed that plant height was not significantly influenced by the spacing between rows in the linseed culture. Silva et al. (2008) and Farinelli et al. (2012) observed that for the corn crop, the reduction of row spacing resulted in a significant decrease in plant height, attributed to the reduction of plant competition in the line by light, water, nutrients and by the stimulation of apical dominance.

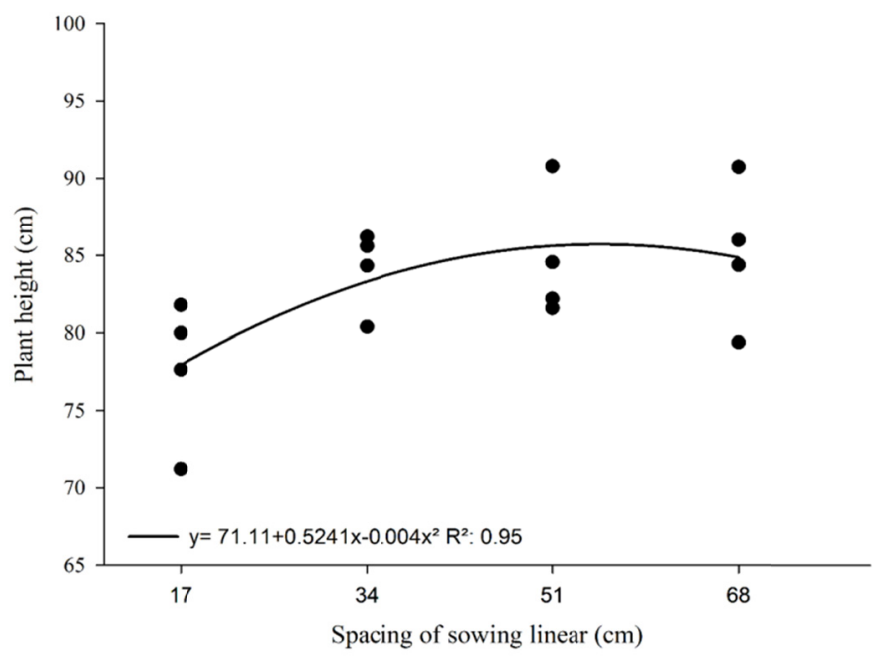

Figure 2. Plants height $(\mathrm{cm})$ of brown linseed at different spacings between the lines 
The dry matter production of the linseed (Figure 3) showed a 29\% variation when compared to the treatments of the extremes, 17 and $68 \mathrm{~cm}$, with the lowest spacing being the highest accumulation of dry matter. There was also a reduction when compared to the spacing $17 \mathrm{~cm}$ with the intermediate spacings, being from $2.4 \%$ to $34 \mathrm{~cm}$ and $3.4 \%$ to that of $51 \mathrm{~cm}$. In contradiction, Santos et al. (2014) did not observe significant variation for dry matter when different linseed spacings were applied.

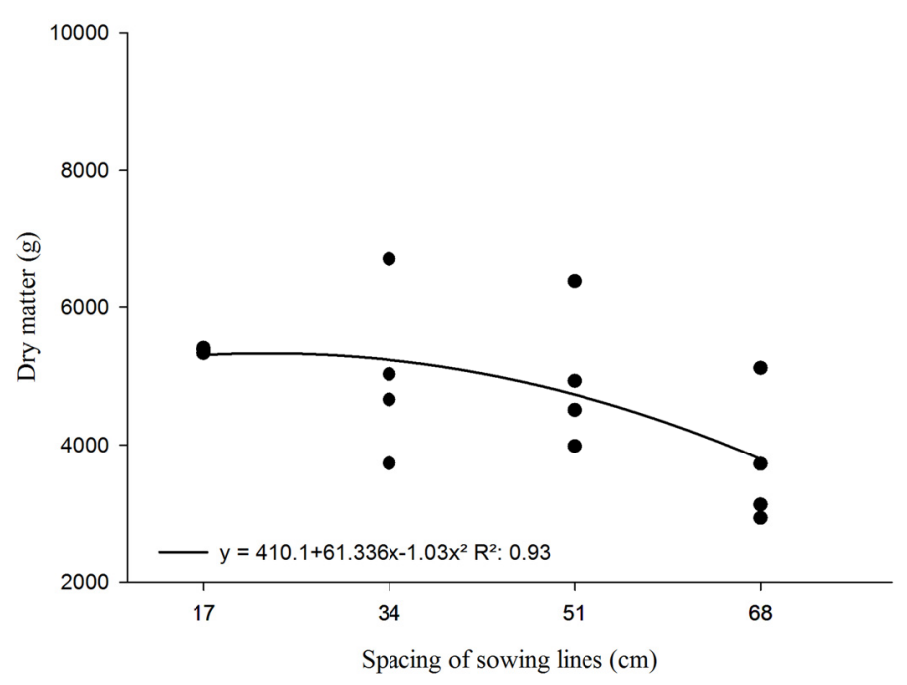

Figure 3. Shoot dry matter $\left(\mathrm{Kg} \mathrm{ha}^{-1}\right)$ of brown linseed in different spacings between the lines

When the observed results for plant height and dry matter variables were compared, they were inversely proportional. It is assumed that in larger spacings the plants prioritize their elongation in the search for solar radiation, besides there is a greater shading of the leaves by the neighboring plants, by the high density in the line, thus reducing the photosynthetic rate and the accumulation of biomass. At reduced spacings, neighboring plants are more distant in the line, with less spatial limitation, so the leaves can intercept more light that arrives in the canopy.

For the variable weight of one thousand seeds (WTS) there was a linear reduction with the increase in the spacing between lines, being the highest weight observed for the treatment with $17 \mathrm{~cm}$ (Figure 4).

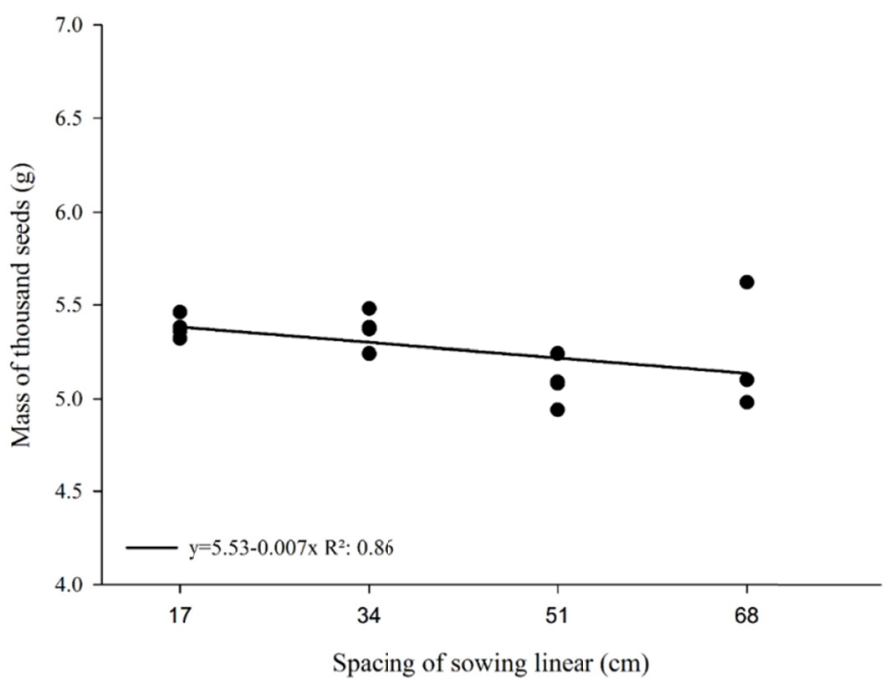

Figure 4. Weight of one thousand brown linseed seeds due to the different spacing between the lines 
The reduction between treatment $17 \mathrm{~cm}$ and 34,51 and $68 \mathrm{~cm}$ was $0.4 \%, 5.4 \%$ and $6.0 \%$, respectively. The weight of one thousand seeds is an important data that can provide an indication of seed quality, and correlates directly with yield (Figure 5). The data on the weight of one thousand seeds as a function of spacing are shown to be contradictory when compared to other studies, such as that developed by Uate et al. (2014), where the authors did not find significant effects between different interlining spacings in the corn crop. In the same sense, also working with the corn crop, Gilo et al. (2011), found that at $45 \mathrm{~cm}$ spacing, the lowest value used was the lowest value for a hundred grain mass.

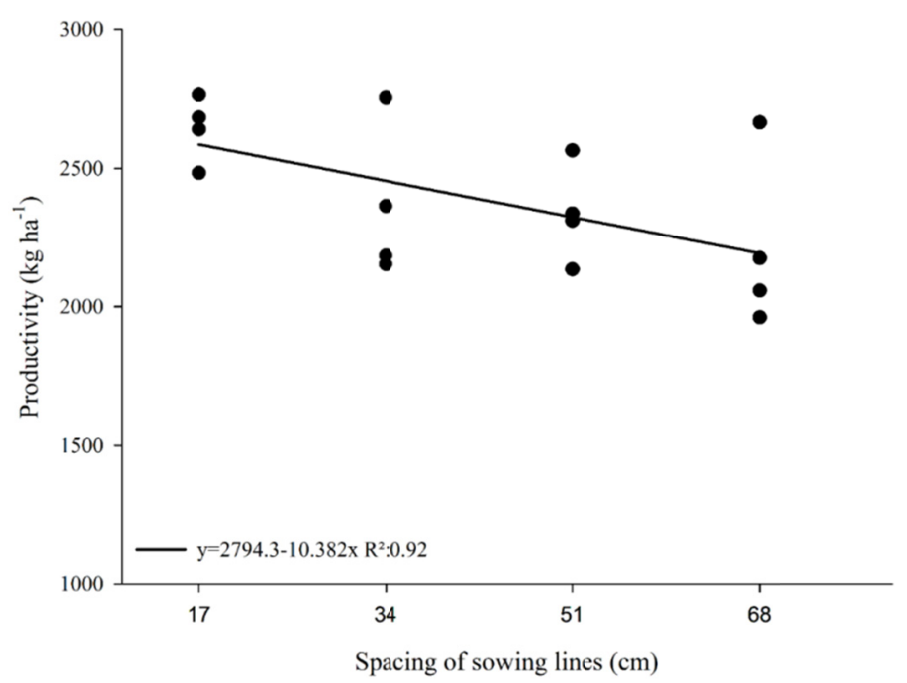

Figure 5. Yield of brown linseed $\left(\mathrm{Kg} \mathrm{ha}^{-1}\right)$ according to the different spacings between the lines

The yield responded in a linear negative way with the increase of the spacing (Figure 5), being in agreement with the one observed in the weight of a thousand seeds. The highest yield per hectare was obtained when the plants were spaced in $17 \mathrm{~cm}$, with a reduction of 10.5, 11.6 and $22 \%$ for the spaces 34,51 and $68 \mathrm{~cm}$, respectively, in comparison with $17 \mathrm{~cm}$. Farinelli et al. (2012), and Vazquez et al. (2012) observed that when the spacing between rows of corn crop was reduced the yield obtained an increase, attributed to more equidistant distributions and all its benefits. By maintaining the same amount of linseed plants per area and reducing the spacing between the lines, the linseed plants are distributed more evenly, with less densified lines. A better arrangement of plants improves the spatial distribution of the leaves and roots of the crop, reducing intraspecific competition. Theoretically, in this situation, the capacity of interception of solar radiation and the use of water and nutrients by linseed may increase, with this, there is an increase in the photosynthetic capacity of the crop and increase in grain yield (Balbinot \& Fleck, 2005).

\section{Conclusion}

The brown linseed cultivated at a spacing of $17 \mathrm{~cm}$ showed lower plant height, which reduces the probability of lodging, higher shoot dry matter, greater weight of one thousand seeds and higher yield. Thus, brownlin seed cultivation isindicated at reduced spacings.

\section{References}

Aisenberg, G. R., Koch, F., Pimentel, J. R., Troyjack, C., Dubal, I., Santos, L. A., ... Aumonde, T. Z. (2018) Soybean growth, solar energy conversion and seed vigour affected by different nitrogen (N) doses. Australian Journal of Crop Science, 12, 343-349. https://doi.org/10.21475/ajcs.18.12.03.pne619

Almeida, K. C. L., Boaventura, G. T., \& Guzmam-Silva, M. A. A. (2009). Linhaça (Linum usitatissimum L.) como fonte de ácido $\alpha$-linolênico na formação da bainha de mielina. Revista de Nutrição, 22(5), 747-754. https://doi.org/10.1590/S1415-52732009000500015

Balbinot Jr., A. A., \& Fleck, N. G. (2005). Redução do espaçamento entre fileiras: Benefícios e limitações. Revista Plantio Direto. 
Caron, B. O., Souza, V. Q., Costa, E. C., Eloy, E., Behling, A., \& Trevisan, R. (2012). Interceptação da radiação luminosa pelo dossel de espécies florestais e sua relação com o manejo das plantas daninhas. Ciência Rural, 42(1), 75-82. https://doi.org/10.1590/S0103-84782012000100013

Carvalho, I. Q. (2007). Espaçamento entre fileiras e população de plantas de milho (p. 117, Dissertação de Mestrado, Universidade Estadual de Ponta Grossa, Brazil).

Carvalho, I. R., Nardino, M., Pelegrin, A. J., Ferrari, M., Demari, G., Szareski, V. J., ... Souza, V. Q. (2016). Path analysis and Annicchiarico method applied in relation to protein in corn grains. Australian Journal of Basic and Applied Sciences, 10, 300-306.

Comissão de Química e Fertilidade do Solo. (2004). Manual de adubação e calagem para os estados do Rio Grande do Sul e Santa Catarina (pp. 33-400). Porto Alegre: Sociedade Brasileira de Ciência do Solo, Núcleo Regional Sul.

Demari, G., Perondi, D., Carvalho, I. R., Nardino, M., Follmann, D. N., Szareski, V. J., ... Souza, V. Q. (2016). Velocidade de semeadura na produtividade da soja Monsoy 5947 ipro $^{\circledR}$. Revista Sodebras, 11, 205-210.

Farinelli, R., Penariol, F. G., \& Fornasieri, F. D. (2012). Características agronômicas e produtividade de cultivares de milho em diferentes espaçamentos entre linhas e densidades populacionais. Científica, 40(1), 21-27. https://doi.org/10.15361/1984-5529.2012v40n1p21+-+27

Gilo, E. G., Junior, C. A. S., Torres, F. E., Nascimento, E. S., \& Lourenção, A. S. (2011). Comportamento de híbridos de milho no Cerrado Sul Matogrossense sob diferentes espaçamentos entre linhas. Bioscience Journal, 27(6), 908-914.

Madalosso, M. G. (2010). Efeito varietal e do espaçamento entre linhas no patossistema soja-Phakopsora pachyrhizi Sidow (p. 109, Tese de Doutorado, Universidade Federal de Santa Maria, Brazil).

Maluf, J. R. T. (2000). Nova classificação climática do Estado do Rio Grande do Sul. Revista Brasileira de Agrometeorologia, 8(1), 141-150.

Nascimento, E. S., Gilo, E. G., Torres, F. E., Junior, C. A. S., Oliveira, L. V. A., \& Lourenção, A. S. (2012). Resposta de híbridos de milho a diferentes espaçamentos entre linhas. Nucleus, 9(2), 131-139. https://doi.org/10.3738/nucleus.v9i2.726

Oliveira, M. R., Santos, R. F., Rosa, H. Á., Werner, O., Vieira, M. D., \& Delai, J. M. (2012). Fertirrigação da cultura de linhaça Linum usitatissimum. Revista Brasileira de Energias Renováveis, 1(1), 22-32.

Penariol, F. G., Filho, D. F., Coicev, L., Bordin, L., \& Farinelli, R. (2003). Comportamento de cultivares de milho semeadas em diferentes espaçamentos entre linhas e densidades populacionais, na safrinha. Revista Brasileira de Milho e Sorgo, 2(2), 52-60. https://doi.org/10.5380/rber.v1i1.33780

Rabetafika, N. H., Remoortel, V. V., Danthine, S., Paquot, M., \& Blecker, C. (2011). Flaxseed proteins: Food uses and health benefits. International Journal of Food Science and Technology, 46(6), 221-228. https://doi.org/ 10.1111/j.1365-2621.2010.02477.x

Sangoi, L. (2000). Understanding plant density effects on maize growth and development: An important issue to maximize grain yield. Ciência Rural, 31(1), 159-168. https://doi.org/10.1590/S0103-84782001000100027

Santos, F. S., Junior, L. A. Z., Dias, P. P., Santos, R. F., \& Pereira, N. (2014). Semeadura da linhaça marrom em diferentes espaçamentos. Acta Iguazu, 3(2), 166-176.

Santos, H. G., Jacomine, P. K., Anjos, L. H. C., Oliveira, V. A., Lumbreras, J. F., Coelho, M. R., ... Oliveira, J. B. (2013). Sistema brasileiro de classificação de solos (3rd ed.). Brasília: Embrapa.

Schek, G. R., Dallastra, A., Fagundes, R. S., \& Pereira, F. L. R. (2008). Fisiologia do milho sobre influência do espaçamento e da densidade populacional. Cultivando o Saber, 1(1), 87-94.

Silva, A. G., Cunha Junior, C. R., Assis, R. L., \& Imolesi, A. S. (2008). Influência da população de plantas e do espaçamento entre linhas nos caracteres agronômicos do híbrido de milho P30K75 em Rio Verde, Goiás. Bioscience Journal, 24(2), 89-96.

Soares, L. L., Pacheco, J. T., Brito, C. M., Troina, A. A., Boaventura, G. T., \& Silva, M. A. G. (2009). Avaliação dos efeitos da semente de linhaça quando utilizada como fonte de proteína nas fases de crescimento e manutenção em ratos. Revista Nutrição, 22(4), 483-491. https://doi.org/10.1590/S1415-52732009000 400004 
Szareski, V. J., Carvalho, I. R., Demari, G. H., Pelissari, G., Pelegrin, A. J., Barbosa, M. H., ... Aumonde, T. Z. (2018). Path analysis applied to agronomic traits of contrasting growth habit soybeans. Australian Journal of Crop Science, 12, 531-538. https://doi.org/10.21475/ajcs.18.12.04.pne608

Szareski, V. J., Carvalho, I. R., Nardino, M., Pelegrin, A. J., Ferrari, M., Gaviraghi, R., ... Souza, V. Q. (2016). Competition of soybean genotypes cultivated in lowlands of Rio Grande do Sul, Brazil. International Journal of Current Research, 8, 39714-39718.

Tomassoni, F., Santos, F., Bassegio, D., Secco, D., Santos, F. S., \& Cremonez, P. A. (2013). Diferentes densidades de plantio na cultura da linhaça dourada. Acta Iguazu, 2(3), 8-14.

Torres, F. E., Langhi, G., Teodoro, P. E., Ribeiro, L. P.,Corrêa, C. C. G., \& Oliveira, E. P. (2013). Desempenho de híbridos de milho cultivados em diferentes espaçamentos na região do cerrado brasileiro. Revista de Ciências Agrárias, 36(4), 411-416.

Uate, J. V., Von Pinho, R. G., \& Cancellier, L. L. (2014). Efeito do espaçamento entre linhas e densidade de plantas na produção da cultura de milho. Revista Científica UEM, 1(1), 13-20.

Vazque, G. H., Garcia, F. P., \& De Assis, A. V. (2012). Influência do espaçamento na produtividade de híbridos de milho sob alta densidade populacional. Revista Brasileira de Engenharia de Biossistemas, 6(27), 9-88.

Wood, I. M. (1997). Fibreb Crops-New opportunities for Australian Agriculture (pp. 18-24). Department of Primary Industries, Brisbane, Australia. https://doi.org/10.18011/bioeng2012v6n2p79-88

\section{Copyrights}

Copyright for this article is retained by the author (s), with first publication rights granted to the journal.

This is an open-access article distributed under the terms and conditions of the Creative Commons Attribution license (http://creativecommons.org/licenses/by/4.0/). 